\title{
Histidine-rich designer peptides of the LAH4 family promote cell delivery of a multitude of cargo
}

\author{
Gilles Moulay, ${ }^{a}$ Christian Leborgne, ${ }^{a}$ A. James Mason, ${ }^{\mathbf{b}, c}$ \\ Christopher Aisenbrey, Antoine Kichler ${ }^{\mathbf{a}, \mathbf{d}}$ and Burkhard Bechinger ${ }^{\mathbf{b}}$ *
}

The histidine-rich designer peptides of the LAH4 family exhibit potent antimicrobial, transfection, transduction and cellpenetrating properties. They form non-covalent complexes with their cargo, which often carry a negative overall charge at pH 7.4 and include a large range of molecules and structures such as oligonucleotides, including siRNA and DNA, peptides, proteins, nanodots and adeno-associated viruses. These complexes are thought to enter the cells through an endosomal pathway where the acidification of the organelle is essential for efficient endosomal escape. Biophysical measurements indicate that, upon acidification, almost half the peptides are released from DNA cargo, leading to the suggestion of a self-promoted uptake mechanism where the liberated peptides lyse the endosomal membranes. LAH4 derivatives also help in cellular transduction using lentiviruses. Here, we compare the DNA transfection activities of LAH4 derivatives, which vary in overall charge and/or the composition in the hydrophobic core region. In addition, LAH4 is shown to mediate the transport of functional $\beta$-galactosidase, a large tetrameric protein of about $0.5 \mathrm{MDa}$, into the cell interior. Interestingly, the LAH1 peptide efficiently imports this protein, while it is inefficient during DNA transfection assays. Copyright @ 2016 European Peptide Society and John Wiley \& Sons, Ltd.

Keywords: cell-penetrating peptide; amphipathic helix; histidine; phosphatidylserine; phospholipid bilayer; endosomal membrane; DNA transfection; protein transduction

\section{Introduction}

Peptides have a great potential in biomedical applications, not only because their building blocks are biodegradable but also due to their reduced size. In addition, key parameters such as product identification and quality control are possible, and these compounds offer the possibility of a reproducible and scalable production process. Lastly, it is possible to (bio)chemically modify the side chains or termini, e.g. by phosphorylation or acetylation, and/or introduce non-natural amino acids into the sequence, further expanding their range of physico-chemical properties. Peptides also serve as template structures to create mimetics, which further extends the range of possible applications [1].

The family of histidine-rich designer peptides of the LAH4 family

T1 (Table 1) was initially designed to investigate the interaction contributions that determine the membrane topology of amphipathic helices using cationic antimicrobial peptides as templates [2]. Many variants have been created over the years [3,4], with members exhibiting potent antibiotic and antiplasmodial action [3], noncovalent nucleic acid complexation and transfection [5,6], other cell-penetrating activities $[7,8]$ and the ability to enhance ex vivo viral transduction, an approach used in clinical gene therapeutic approaches $[9,10]$.

The core of the LAH4 peptides consists of alanines and leucines where four histidines are interspersed (Table 1). An amphipathic helix forms in membrane environments where all four histidines are localized on one face. Two lysines at each terminus assure good solubility of the peptides in aqueous environments, serve as membrane interfacial anchors and also aid in nucleic acid binding [11].
In membrane environments, where the LAH4 peptides exhibit a high propensity to adopt $\alpha$-helical conformations, the histidines exhibit pK values between 5.4 and 6.0, and thereby, these residues allow one to tune the hydrophobic moment of these sequences by changing the $\mathrm{pH}$ [12]. Therefore, $\mathrm{LAH} 4$ aligns parallel to the surface of phosphatidylcholine bilayers at $\mathrm{pH}<6$ and adopts a

* Correspondence to: Burkhard Bechinger, Institut de Chimie, 4, Rue Blaise Pascal, 67070 Strasbourg, France. E-mail: bechinge@unistra.fr

Contribution to the special issue following the 15th Naples Workshop on Bioactive Peptides in June 2016 (guest editor Giancarlo Morelli)

a Genethon, 1bis rue de I'Internationale, 91002, Evry, France

b Université de Strasbourg, CNRS, UMR7177, Institut de Chimie, 4, Rue Blaise Pascal, 67070, Strasbourg, France

c Institute of Pharmaceutical Science, King's College London, 150 Stamford Street, London, UK

d LabEx Medalis, Faculté de Pharmacie, Laboratoire de Conception et Application de Molécules Bioactives UMR7199 CNRS - Université de Strasbourg, 67401, Illkirch, France

Abbreviations used: Aib, $\alpha$-aminobutyric acid; CMV, cytomegalovirus; DOPC, 1,2dioleoyl-sn-glycero-3-phosphocholine; DOPG, 1,2-dioleoyl-sn-glycero-3-phosphorac-(1-glycerol); DPPA, 1,2-dipalmitoyl-sn-glycero-3-phosphate sodium salt; NMR, nuclear magnetic resonance; PBS, phosphate-buffered saline; PC, 1,2-diacyl-snglycero-3-phosphocholine; POPS, 1-palmitoyl-2-oleoyl-sn-glycero-3-phospho-Lserine; PS, 1,2-diacyl-sn-glycero-3-phospho-L-serine; X-Gal, 5-bromo-4-chloro-3indolyl- $\beta$-D-galactopyranoside 


\begin{tabular}{|c|c|c|c|c|c|c|c|c|}
\hline Peptide & Sequence & $\begin{array}{l}\text { Nominal } \\
\text { charge } \\
\mathrm{pH} 7.4\end{array}$ & $\begin{array}{l}\text { Nominal } \\
\text { charge } \\
\text { pH } 5\end{array}$ & $\begin{array}{l}\text { Hydrophobic } \\
\text { moment } \\
(\mathrm{pH} \mathrm{7})^{\#}\end{array}$ & $\begin{array}{l}\text { Polar } \\
\text { angle }^{\#}\end{array}$ & $\begin{array}{l}\text { Transfection } \\
\text { efficiency }^{\dagger}\end{array}$ & Cell lines investigated & Reference \\
\hline $\mathrm{LAH} 4$ & KKALLALALHHLAHLALHLALALKKA & 5 & 9 & 0.19 & 120 & ++++ & HepG2, MRC5-V2, HEK293 & [22] \\
\hline LAH4-L1 & KKALLAHALHLLALLALHLAHALKKA & 5 & 9 & 0.25 & 100 & ++++ & HepG2, MRC5-V2, HEK293 & {$[5]$} \\
\hline LAK4 & KKLAKALAKALAKALKLALALAKK & 9 & 9 & 0.46 & 100 & + & HepG2 & [22] \\
\hline LAH1 & KKLALALALALHALALALALKKA & 5 & 6 & 0.09 & 20 & ++ & HepG2 & [22] \\
\hline $\mathrm{LAH} 2$ & KKLAHLALALALGLALAHLAKKA & 5 & 7 & 0.03 & 160 & + & HepG2 & [22] \\
\hline LAH3 & KKALALGLHLAHLALHLALALKKA & 5 & 8 & 0.10 & 80 & + & HepG2 & [22] \\
\hline LAH5 & KKALLALALHHLAHLAHHLALALKKA & 5 & 10 & 0.26 & 140 & ++++ & HepG2 & [22] \\
\hline LAH4-P15 & KKALLALALHHLAHPALHLALALKKA & 5 & 9 & 0.16 & 120 & + & HepG2 & [23] \\
\hline D-LAH4 & KKALLALALHHLAHLALHLALALKKA & 5 & 9 & 0.19 & 120 & ++ & HepG2 & [23] \\
\hline LAH4-L1-F4* & KKALLAHFFHLLALLALHFFHALKKA & 5 & 9 & 0.31 & 100 & ++++ & HepG2 & [19] \\
\hline LAH4-L1-F2d & KKALLAHFLHLLALLALHLFHALKKA & 5 & 9 & 0.31 & 100 & ++++ & HepG2 & - \\
\hline LAH4-L1-Opt & KKLALAHALHLALLLALHLAHALKKA & 5 & 9 & 0.09 & 100 & +++ & MRC5-V2 & - \\
\hline LAH4 inv-AL & KKALLALALHHALHLALHLALALKKA & 5 & 9 & 0.11 & 120 & ++++ & MRC5-V2 & - \\
\hline LAH4-L1- $\beta$ & KKALAHALHLLALALLHLAHALAKK & 5 & 9 & 0.27 & 100 & ++++ & MRC5-V2 & - \\
\hline $\mathrm{LAH} 4 \mathrm{X} 2$ & KKALLALAXHHLAHLALHXALALKKA & 5 & 9 & 0.16 & 120 & ++ & HepG2 & - \\
\hline $\mathrm{LAH} 5 \mathrm{X} 2$ & KKALLALAXHHLAHLAHHXALALKKA & 5 & 10 & 0.23 & 140 & + & HEK293 & - \\
\hline LAK5X2 & KKALLALAXKKLAKLAKKXALALKKA & 10 & 10 & 0.39 & 140 & + & HEK293 & - \\
\hline LAK5X2W2 & KKALLALAXKKWAKLWKKXALALKKA & 10 & 10 & 0.49 & 140 & + & HEK293 & - \\
\hline \multicolumn{9}{|c|}{$\begin{array}{l}{ }^{\dagger} \text { To the luciferase activity obtained with } \mathrm{LAH} 4 \text { and LAH4-L1, we gave the value } 1000(=++++) \text {. The transfection efficiency was scaled using the following } \\
\text { code: }+, 0-9 ;++, 10-99 ;+++, 100-499 ;++++, 500 \text { to } \geq 1000 \text {. The experiments were performed in duplicates. X, alpha amino butyric acid. } \\
\text { *Sequence has been published but not the transfection activity. } \\
\text { "The helical wheels were calculated without the amino-terminal and carboxy-terminal } \mathrm{K} \text { and final A; the hydrophobicity of Aib residues was approximated } \\
\text { by that of } \mathrm{V} \text {. The definition of the polar angle includes the full extent of the flanking } \mathrm{H} \text { residues and is therefore increased by } 20^{\circ} \text { when compared with } \\
{[[5]] \text { where the separation between polar and hydrophobic side was defined mid-way through these amino acids. }}\end{array}$} \\
\hline
\end{tabular}

transmembrane orientation when the histidines are uncharged [13]. At intermediate $\mathrm{pH}$, a flexible domain probably facilitates the membrane insertion during the in-plane to transmembrane transition [12]. The midpoint $\mathrm{pH}$ of the main conformational transition in solution of a number of $\mathrm{LAH} 4$ derivatives was also investigated with even lower values observed [14]. As the transition is reversible, it is possible to evaluate the transfer energy of amino acid side chains from the membrane interface to the membrane interior [15]. Furthermore, dynamic light scattering, CD spectroscopy and fluorescence self-quenching data indicate that, in aqueous buffers, the peptides disperse in the shape of small $\alpha$-helical aggregates at neutral $\mathrm{pH}$ but exhibit the hydrodynamic radius of extended monomers in acidic solutions [16,17]. Following the discovery of LAH4 [2], another peptide with $\mathrm{pH}$-dependent membrane topology and potential biomedical applications has been developed [18]. This sequence encompasses two aspartic acids and adopts the reverse membrane topology, i.e. transmembrane at low $\mathrm{pH}$ and associated with the membrane surface at high $\mathrm{pH}$.

Members of the LAH4 family of peptides exhibit membrane pore formation in model membranes [16] and antimicrobial action at both neutral and, to an even larger extent, acidic $\mathrm{pH}$ [3] against clinical isolates [19]. Importantly, when the helices align parallel to the membrane surface, they associate into mesophase arrangements of high local density [17]. The interactions of the peptides with the bilayer interface result in a decreased order parameter of the phospholipid fatty acyl chains and considerable curvature strain on the membrane [20].

Some of the LAH4 peptides exhibit excellent DNA [21] and siRNA transfection activities with higher efficiencies than that of well-

Q4 established compounds such as lipofectamine, DOTAP and polyethylenimine [6]. The simultaneous antimicrobial and DNA transfection activities of these peptides, which are both retained in the complexes with DNA, are of potential interest for multimodal applications [21], e.g. in hereditary diseases such as cystic fibrosis, where Pseudomonas aeruginosa infections are a major complication.

When the peptides and DNA are mixed at $\mathrm{pH} 7.4$, large transfection complexes are formed, which enter the cells via an endosomal pathway [21]. Zeta-sizer measurements indicate that the complexes carry an overall small positive surface charge density [22]. The size of the complexes can be tuned by changing the salt concentration, thus obtaining hydrodynamic diameters in the $100 \mathrm{~nm}$ to micrometer range [22]. It has been shown by ${ }^{13} \mathrm{C}$ magic angle spinning solid-state NMR spectroscopy that LAH4 adopts an $\alpha$-helical conformation in the pure peptide powder as well as in the transfection complex [23]. Solid-state NMR distance measurements show that the positive lysine termini of the peptide, rather than the histidines, interact with the negatively charged phosphates of the DNA [11]. With two lysine side chains at each terminus, the peptide thereby interconnects distant parts of the extended DNA molecule, as well as different DNA strands, thereby leading to the observed condensation of this anionic biopolymer. With the help of biophysical investigations, a mechanistic model for the self-promoted uptake and release and the intracellular processes that occur during nucleic acid transfection by LAH4 peptides could be established [23] and will be discussed later.

Furthermore, LAH4 sequences have been shown to act as cellpenetrating peptides not only for pDNA, siRNA and CpG oligonucleotides [8] but also for quantum dots [7], lentiviruses used in ex vivo gene therapeutic approaches [4], adeno-associated viruses (AAV, [10]) and protein-based and peptide-based vaccines [8]. In the latter cases, the main goal was to expose the proteins to an endosomal processing; thus, peptide fragments are presented 
by MHC-I receptors, and this in turn can induce an immune response by CD8+ T cells. However, the question remains if this approach can be more general and include proteins that arrive as functional entities in the cytoplasm because this could open new therapeutic perspectives. Indeed, the problem with proteins that target intracellular biological activity such as p53, cytochrome $\mathrm{c}$ and many others is that their cytosolic delivery is difficult because most proteins are unable to spontaneously enter mammalian cells. Different protein delivery technologies have been developed [24-27]. Most of them rely on the fusion or conjugation to cationic molecules, as, e.g. cell-penetrating peptides [28]. Intracellular delivery efficiencies were unfortunately uneven and depend on several parameters.

Here, our previous investigations were extended by focusing on three mechanistic aspects. First, we will focus on the role of the membranes by asking if it is possible to ameliorate the transfection activities by enriching the cellular membrane with acidic phospholipids such as phosphatidylserines. Second, in order to further evaluate the role of electrostatic and hydrophobic contributions, a number of peptides are reviewed and presented that vary in their charge composition at $\mathrm{pH} 7.4$ and/or $\mathrm{pH}$ 5. Third, we asked whether these peptides are able to deliver a protein into mammalian cells simply after co-incubation of the cellpenetrating peptides with the target protein and to keep it functional during the transduction process.

\section{Materials and Methods}

\section{Materials}

The peptides (Table 1) were prepared by solid-phase peptide synQ6 thesis using a Millipore 9050 automatic peptide synthesizer and the standard cycles for Fmoc chemistry with amino acids from Merck-Novabiochem (Fontenay sous Bois, France). The preparations showed one predominant peak, which was purified by reverse-phase HPLC (Gilson, Villiers-le-Bel, France) using a preparative $\mathrm{C} 18$ column (e.g. Luna, C18-300 $\AA-5 \mu \mathrm{m}$, Phenomenex, Le Pecq, France) and an acetonitrile/water gradient. The main peak was collected, and its identity and purity (>90\%) were checked by analytical HPLC and MALDI mass spectrometry (MALDI-TOF Autoflex, Bruker Daltonics, Bremen, Germany). The purified peptide was lyophilized and stored at $-20^{\circ} \mathrm{C}$.

Cytomegalovirus (CMV)-Luc (SMD2-LuCDITR plasmid of $7.6 \mathrm{~kb}$ ) is an expression plasmid encoding the firefly luciferase gene under the control of the human CMV immediate-early promoter. PS from bovine brain ( $\geq 98.0 \%)$, DOPG, DPPA and DOPC were obtained from Sigma-Aldrich (St. Quentin Fallavier, France).

\section{Cell Culture}

Dulbecco's modified Eagle medium (Thermo Fisher, Illkirch, France) was supplemented with $2 \mathrm{mM} / \mathrm{I}$ glutamine, 100 units/ml penicillin, $100 \mu \mathrm{g} / \mathrm{ml}$ streptomycin and $10 \%$ of fetal calf serum. We used human hepatocarcinoma cells (HepG2 cells) for the protein transduction assays. For the PS enrichment assays, we used the following two cell lines: SV40-transformed human fetal lung fibroblast MRC-5 cells (MRC5-V2) and the murine embryonic fibroblast cell line NIH3T3.

\section{Treatment of Cells with Phosphatidylserine}

Phosphatidyl-L-serine dissolved in a chloroform/methanol (95:5) mixture was dried in a glass tube and resuspended in PBS to a final concentration of $5 \mathrm{mM}$. Liposomes were generated from this solution using a water bath sonicator. The protocol was the same for the PC-based, PG-based and PA-based liposomes. Cells plated in 24-well plates were then incubated with increasing concentrations of PS (added to serum-containing medium) for $24 \mathrm{~h}$. The successful enrichment of cell membranes of two cell lines (MRC5-V2 and $\mathrm{NIH} 3 \mathrm{T3}$ ) with PS was demonstrated using a fluorescently labelled annexin V (Annexin V FITC detection kit from BD Pharmingen, Le Q7 Pont de Claix, France). This protein binds tightly and specifically to PS and is commonly used to measure cell surface PS levels. The efficiency of enrichment was evaluated using flow cytometry by comparing treated versus non-treated cells.

\section{DNA Transfection Experiments}

Cells were plated in 24-well plates 2 days before transfection. At day 1 , the cells were incubated or not with PS for $24 \mathrm{~h}$. At day 2, the cells were transfected using the following protocol: $4 \mu \mathrm{g}$ of DNA (CMVLuc) and the desired amount of peptide were each diluted in $100 \mu \mathrm{l}$ of $150 \mathrm{mM} \mathrm{NaCl}$. Peptide and DNA solution were mixed and incubated for $15 \mathrm{~min}$ at room temperature. Notably, under these experimental conditions, the size of the complexes is in the micrometer range [22]. Before adding the complexes to the cells, the mixtures were diluted with serum-free medium to a final volume of $1 \mathrm{ml}$. Experiments were performed in duplicate $(0.5 \mathrm{ml}$ per well). After about $3 \mathrm{~h}$, the transfection medium was replaced with fresh medium containing $10 \%$ serum. Cells were harvested $30 \mathrm{~h}$ after the beginning of the transfection experiment, and the luciferase activity was measured as previously described [29].

\section{Preparation of the Peptide/Protein Complexes}

A total of $0.5 \mu \mathrm{g}$ of avidin- $\beta$-Gal and increasing amounts of LAHderived peptide or polylysine with a degree of polymerization of $\approx 20$ (Sigma-Aldrich, St. Quentin Fallavier, France) were each diluted in $50 \mu \mathrm{l}$ of calcium-free PBS and gently mixed. After $30 \mathrm{~min}$ of incubation at room temperature, the mixture was diluted with serumfree medium to a final volume of $0.4 \mathrm{ml}$.

\section{Protein Transduction Experiments}

A total of 240000 HepG2 cells were plated in 24-well plates 1 day before the experiment. Before transduction, the cells were rinsed once with PBS. A total of $0.4 \mathrm{ml}$ of serum-free medium containing the complexes was then transferred into each well. After an incubation time of $3 \mathrm{~h} 30$ at $37{ }^{\circ} \mathrm{C}$, the medium was removed, and cells Q9 were washed twice with PBS, fixed and stained with X-Gal. Briefly, cells were washed twice with PBS, fixed in $0.5 \%$ glutaraldehyde for $20 \mathrm{~min}$ at $4{ }^{\circ} \mathrm{C}$ and washed again. Then, the cells were incubated overnight at $37^{\circ} \mathrm{C}$ with X-Gal. Finally, the cells were washed again twice with PBS before the transduction efficiency was evaluated.

\section{Results}

\section{Enhancement of Transfection by Phosphatidylserine and Phosphatidylglycerol}

We previously studied the effect of LAH4 (Table 1) and derivatives on lipid vesicles in the presence of PS using non-perturbing solidstate NMR techniques [5,29]. Proton-decoupled ${ }^{31} \mathrm{P}$ magic angle spinning NMR of the phospholipid head groups revealed an electrostatic interaction between LAH4 and POPS. Furthermore, a close 
correlation exists between the transfection efficiency of the peptides on cells cultured in vitro, with the disruption of POPS chain order as observed with wide line ${ }^{2} \mathrm{H}$ NMR of chain-deuterated POPS. Notably, these data indicate that in mixed PC/PS membranes, the cationic peptides selectively interact with the anionic phospholipids. On the other hand, Coil and Miller reported that the enrichment of cell membranes with PS can increase the entry of enveloped viruses [30]. Taking into consideration these results, we asked whether pre-treatment of cultured cells with PS could also increase the transfection efficiency of LAH4.

First, we checked whether by pre-incubation of the cells with phosphatidylserine liposomes (cf. Materials and Methods section), we were able to successfully enrich the cell membranes of two cell lines (NIH3T3 and MRC5-V2) with PS. To this end, we used fluorescently labelled annexin $\mathrm{V}$ - a protein that binds specifically to PS and that is commonly used to measure cell surface PS levels. The results showed that the cell surface content in PS increased in both

F1 cell lines (Figure 1) as described previously by Coil and Miller [30].

Next, after $24 \mathrm{~h}$ of incubation of the cells with PS (or other lipids),

F2 a transfection experiment was conducted. As shown in Figure 2(A), incubation of cells with PS (from bovine brain) increases in a dosedependent manner the transfection efficiency. Using the same protocol, DOPC did not impact the efficiency. Next, we asked whether other negatively charged lipids can mimic the effects of PS. As shown in Figure 2(B), DOPG was also able to increase the activity of LAH4, while this was not the case for DPPA. Finally, we found that the effect of PS on the efficiency of the LAH4 peptide could be reproduced on another cell line [Figure 2(C)].

\section{Evaluation of Different LAH4 Mutants}

The data shown in Figure 2 suggest that after PS or DOPG treatment, the increased transfection is due to electrostatic attraction of the positively charged transfection complexes [22] to the negatively charged surface of the outer monolayer of the membrane. This fits well with the experiments showing that deficiency of the cell surface of anionic heparan sulfate proteoglycans strongly reduces the transfection activity of cationic carriers [31].

Notably, electrostatic interactions between the peptide and the nucleic acids have already been shown to be important for LAH4 transfection [23]. Changing the overall charge of the peptide provides another means to modulate interactions with the cargo, the plasma and the endosomal membranes. In Table 1, the transfection efficiencies of a number of peptide sequences are reviewed and new data are added, where the overall nominal charge at $\mathrm{pH} 5$ and at $\mathrm{pH} 7.4$ is compared with each other. For the table, the pK of histidines has been assumed 6.0 although in membrane environments, somewhat lower values have been determined experimentally [12]. Furthermore, the amino-terminus is considered charged at $\mathrm{pH} 7.5$ and $\mathrm{pH} 5$ although its $\mathrm{pK}$ can be relatively close to neutral. Therefore, the table probably over-estimates the number of positive charges, but the general trends are still apparent.

Table 1 shows a comparison of the transfection efficiency of various sequences. The terminal lysines have been shown to be the contact sites between DNA and the transfection peptides and have therefore not been modified here [11]. Notably, when additional lysine replaces the four histidines in LAK4, transfection activity is also inhibited [21]. With four lysines at the termini, at least four histidines are required for good activity [21]. Modifications of the core residues have revealed that efficient endosomal release was correlated to the transition from transmembrane to in-planar alignments in model membranes upon acidification $[21,32]$. Therefore, significant transfection activity is retained upon the introduction of two or four phenylalanine residues in the core region (LAH4-L1-F4; LAH4-L1-F2d; Table 1). Similarly, re-arranging some of the hydrophobic amino acids (LAH4-L1-Opt; LAH4-L1- $\beta$; and $\mathrm{LAH} 4$ inv-AL) has relatively little effect on transfection efficiency. In contrast, the presence of a proline in the core region [22] or of Aib residues has large effects on the transfection efficiency (Table 1) when at the same time, the latter amino acid increases the antimicrobial activities against a number of bacteria and fungi (unpublished).

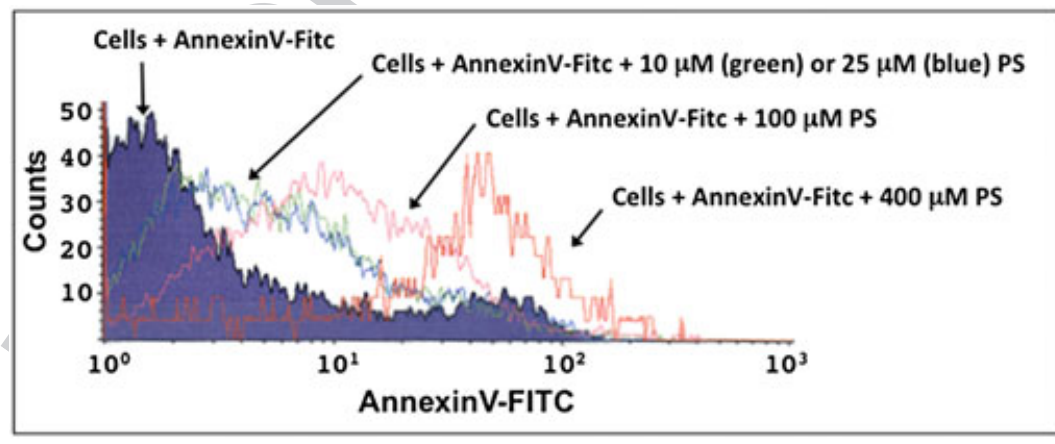

NIH3T3

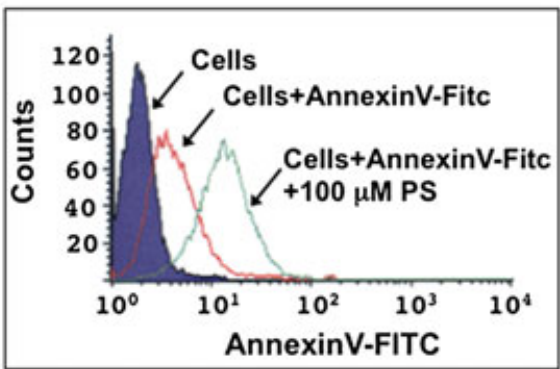

MRC5-V2

Q8 Figure 1. Cell surface enrichment in PS. NIH3T3 and MRC5-V2 cells were incubated for $24 \mathrm{~h}$ with PS. The successful enrichment of the plasma membranes of the two cell lines with PS was demonstrated using a fluorescently labelled annexin V. 

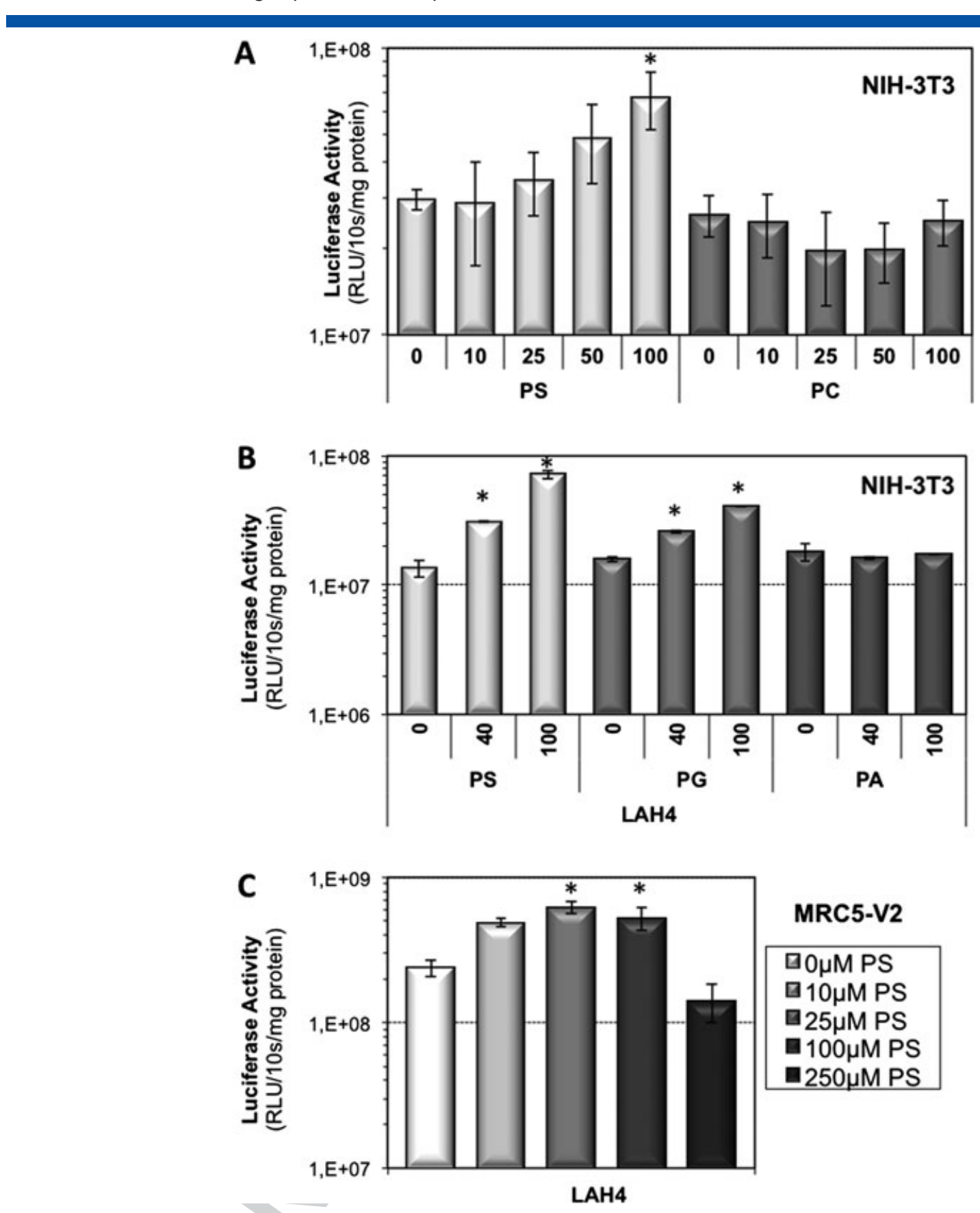

Figure 2. Effect of lipid pre-treatment on the transfection efficiency of LAH4. NIH3T3 (A and B) and MRC5-V2 (C) cells were incubated for $24 \mathrm{~h}$ with various concentrations either PS (bovine brain), DOPG, DPPA or DOPC. The numbers reported for phospholipid contents refer to micromolar concentrations. Cells were subsequently transfected with $40 \mu \mathrm{g} \mathrm{LAH} 4 / 4 \mu \mathrm{g} \mathrm{CMV-Luc} \mathrm{complexes} \mathrm{(w/w} \mathrm{ratio} \mathrm{of} \mathrm{10/1),} \mathrm{and} \mathrm{the} \mathrm{luciferase} \mathrm{activity} \mathrm{was} \mathrm{measured} 30 \mathrm{~h}$ posttransfection. The experiments were performed in duplicates. ${ }^{*} p<0.05$ with respect to untreated cells, one-way analysis of variance with Bonferroni post hoc test.

\section{Protein Transduction Assays}

Finally, we tested the capacity of three different LAH-derived peptides, namely, LAH1, LAH4 and LAK4 (Table 1), to deliver a protein into a human hepatocytic cell line. Each peptide was mixed at different $\mathrm{w} / \mathrm{w}$ ratios in PBS with $0.5 \mu \mathrm{g}$ of avidin- $\beta$-galactosidase. The mixtures were then diluted in serum-free culture medium and added to the cells. A few hours later, the cells were stained. The results show that with $5 \mu \mathrm{g}$ of $\mathrm{LAH} 4$, an impressive number of HepG2 cells present blue dots, while in the absence of LAH4 (avidin- $\beta$-Gal alone) or in the non-treated cells, no cells were $\beta$-Gal positive
(Figure 3). Notably, because the protein is delivered and not the F3 gene, it is expected that the cells do not present a homogenous staining. To check whether it is only the cationic nature of LAH4 that is required for the protein delivery, we used the peptide LAK4 and a poly-L-lysine with a degree of polymerization of around 20. Interestingly, although there was an increased staining, as compared with $\beta$-Gal alone with both carriers, it was still significantly lower than the one obtained with LAH4. One interesting point to mention is that LAH1, while 50 times less efficient than LAH4 in gene delivery experiments, promoted protein transduction with a comparable efficacy than LAH4 (Table 1). 


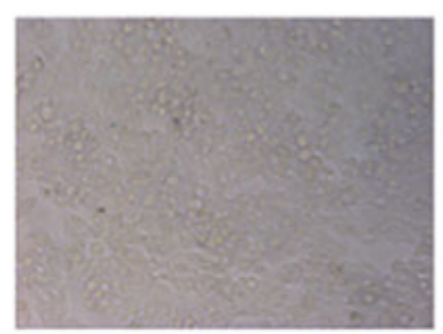

Cells
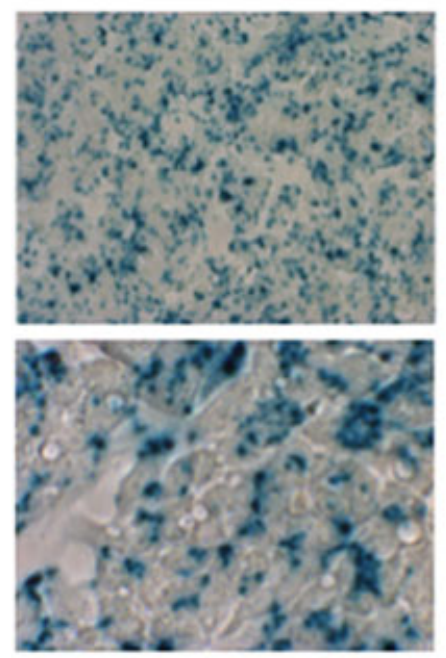

LAH4 $(5 \mu \mathrm{g})$

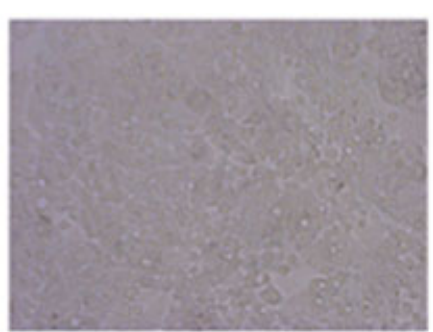

Avidin-ß-Gal
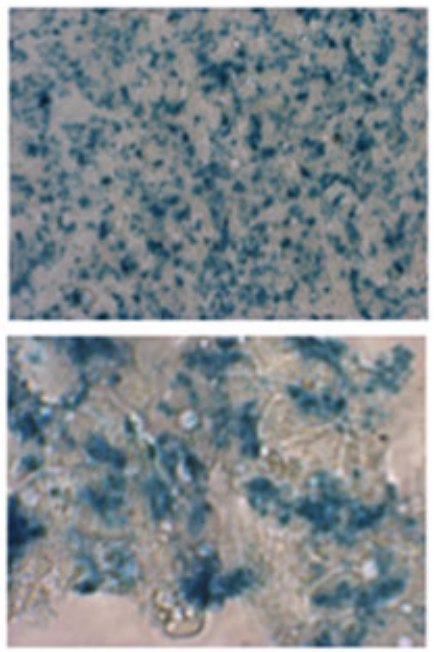

LAH1 $(10 \mu \mathrm{g})$

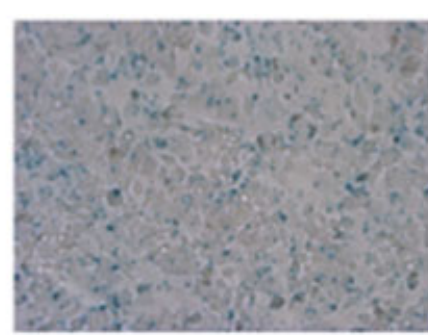

pLys $20(10 \mu \mathrm{g})$
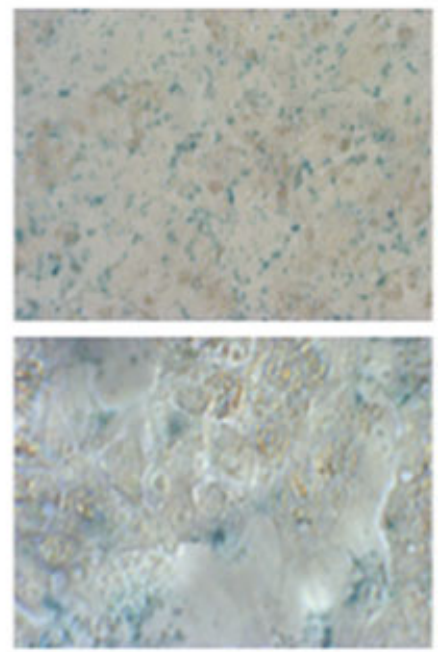

LAK4 $(20 \mu \mathrm{g})$

Figure 3. Peptide-mediated delivery of avidin- $\beta$-Gal into HepG2 cells. Increasing amounts of peptide were mixed with a constant amount of avidin- $\beta$-Gal $(0.5 \mu \mathrm{g}$ per well). The complexes were incubated for $3 \mathrm{~h} 30$ with HepG2 cells plated in 24 -well plates the day before. $\beta$-Gal activity was revealed after X-Gal staining. Only the best formulation for each compound is shown. Magnification $\times 10$ for the photos shown at the top and in the middle and magnification $\times 40$ for the photos at the bottom.

\section{Discussion}

The family of LAH4 peptides has excellent capabilities to transfer small molecules such as exon skipping oligonucleotides [33] or very large cargoes such as a 7600 bp plasmid DNA $\left(M W=5 \times 10^{6}\right)$ into the cell interior. It has been demonstrated that the peptide/DNA transfection complexes enter via an endosomal pathway [21]. By dissecting the biophysical properties of LAH4 and its complex, a model was established where transfection complexes of $100 \mathrm{~nm}$ to several micrometer diameter are formed outside the cells at $\mathrm{pH}$ 7.4 [22]. The supramolecular structures are governed by a very high coverage of peptide (about one peptide per $2 \mathrm{bp}$ ) [23]; thus, the negative surface potential of DNA converts into a slightly positive one of the complexes [22]. Acidification in the endosome causes the release of a large proportion of LAH4 peptides from the DNA, which are then free to interact and probably lyse the membranes [23]. Such efficient endosomal release is probably the reason for the very good transfection activities of LAH4 for both siRNA [6] and DNA [21]. Whereas the first can now reach its cytoplasmic targets, the latter needs to continue its voyage to the nucleus, which could explain why significant efforts to achieve better DNA transfection by sequence variations of LAH4 resulted in only relatively small additional improvements in transfection activities [5]. Notably, the LAH4 peptides have also been shown highly efficient for transferring a variety of cargoes into cells including $\mathrm{CpG}$ oligonucleotides [8], proteins (Figure 3) [8], AAV [10], lentiviruses [4] and quantum dots [7].

\section{Self-association of Complexes}

In order for the LAH4 peptides to be efficient during transfection, non-covalent complexes are formed with the nucleic acids and other cargo. Therefore, in all cases known to us, the cargo was mixed with the LAH4 peptide and shortly incubated. The noncovalent nature of the complex assures that the information carried by the nucleic acids can be released and becomes easily available at their cytoplasmic or nuclear destination, respectively. A tighter association of all-D-LAH4 with the DNA could be a reason why this peptide is less efficient in transfection assays than the L-enantiomer (Table 1), although it should be noted that the phospholipids also have stereo-specific properties. Whereas all-D and all-L antimicrobial peptides have been shown to be equally active [34], the situation may be different for the interactions between DNA, membranes and the transfection peptides investigated here. Alternative approaches have been developed for other cell-penetrating peptides where a covalent linkage is cleaved in the reducing environment of the cell interior, but this has so far not been tested for LAH4 [35].

Therefore, the question arises how such a wide variety of compounds can non-covalently interact with the cationic amphipathic LAH4 peptides? For DNA, it has been shown previously that electrostatic interactions of the lysines and the phosphates play an important role during complex formation [11,23]. The association between peptide and DNA results in an overall cationic complex not far from charge neutrality $[22,23]$, which results in the release of considerable amounts of peptide when the $\mathrm{pH}$ drops around 
the pK of the histidines, thereby making the peptides more positive (Table 1). The peptide association with siRNA and oligonucleotides can be explained in a similar manner.

LAH4 peptides have also been used to transfer proteins and peptides into cells [8] (Figure 2). The pl values of ovalbumin (44 kDa), whose intracellular delivery is reported in reference [8], and avidin- $\beta$-galactosidase (530 kDa; [36]) are $<5$ when extracted from technical data sheets or by applying an algorithm for such calculations [37], indicating that these proteins are negatively charged at $\mathrm{pH} 7.4$ or 5 . The pl of firefly luciferase $(61 \mathrm{kDa})$ around 6.1 is indicative that the protein changes from negative to positive inside the endosome, thereby further promoting the release of LAH4. Notably, not only LAH4 was used to deliver the protein directly into the cell [8] but, alternatively, also a plasmid encoding its sequence has been used as a convenient monitoring system for efficient DNA transfection [21]. For the donkey lgG antibody used in [8], information about the pl is limited. However, sequence information about exons 1-4 of the closely related horse lgG heavy chains subclasses 4 and 7 $[38,39]$ suggests a pl close to neutral, which corresponds to pl data for other lgGs found in mammalian serum. IgG antibodies typically have an $M W$ around $150 \mathrm{kDa}$ [40]. Consistently, the peptides used in the LAH4-aided immunization all carried a net negative charge [8].

When the LAH4-mediated increase in transduction of viral particles was investigated, the presence of 100 or $500 \mathrm{mM}$ phosphate considerably reduced the efficiency [10], suggesting that also in this case, electrostatic interaction contributions are important for complex formation and cellular import. Indeed, negative surface potentials were measured for AAV2 capsids using zeta-sizer measurements [41,42]. On average, 2700 LAH4 molecules have been found associated with one viral particle during the transduction experiments [10], which corresponds to a more than complete coverage of a sphere of $20 \mathrm{~nm}$ diameter (the approximate size of AAV [43]) with helical peptides. Similarly, an average of 50 peptides has been found to be associated with each quantum dot (a few nanometers in diameter) functionalized with PEG-dehydrolipoic acid ligands [7], which thereby offer an amphipathic polar surface for peptide association.

Notably, the avidin- $\beta$-galactosidase $(530 \mathrm{kDa})$ presented here is to our knowledge the biggest protein imported so far (Figure 3) by LAH4 cell-penetrating peptides, when at the same time, the 7600 bp DNA plasmid ( $\approx 5 \mathrm{MDa}$ ) [21] or an adeno-associated viral particle $[10,44]$ represents an order of magnitude larger cargo.

\section{Interactions with the Membrane}

During the incubation of cargo with the cationic peptides, an overall positively charged complex is formed $[22,41]$, whose interactions with the cellular and cytoplasmic membranes should be favored by negatively charged surfaces. It has been shown previously that LAH4 preferentially interacts with anionic lipids such as PS in mixed PC/PS membranes [5]. The increased transfection efficiency after incubation of the cells with PS (from bovine brain) or DOPG, but not with DOPC, can be explained by changes in the membrane composition that result in an increased concentration of cationic molecules/complexes next to the now anionic membranes [45]. Notably, $24 \mathrm{~h}$ after treatment, increased annexin $\mathrm{V}$ binding indicates that the PS content of the outer membrane monolayer remains elevated, suggesting the stable enrichment of PS in the outer monolayer (Figure 1). The addition of the anionic lipid DPPA did not have an effect on the transfection efficiency. When compared with DOPG and PS from bovine brain, this lipid carries a much smaller head group. It is possible that the resulting cone-shaped geometry of the lipid stabilizes the endosomal membrane in the presence of amphipathic peptides [46], thereby counter-acting the more efficient membrane association. Furthermore, the saturated fatty acyl chains of DPPA and the correspondingly high-phase transition temperature $\left(75^{\circ} \mathrm{C}\right)$ could be a reason for the absence of transfection enhancement. Similarly, differences in transfection efficiency are observed between cell lines (e.g. [21,47]), which could involve the composition of the membrane, receptors or other cellular features such as the cell division rate, a process that provides access of cytoplasmic DNA to the nucleus [48].

\section{Endosomal Uptake and Escape}

In the next steps of the transfection process, the peptide-cargo complex is taken up by the endosome, where acidification of this organelle is an essential step for efficient release into the cytoplasm [21]. Isothermal titration calorimetry indicates that under saturating conditions, and at $\mathrm{pH} 7.5$, one peptide is associated with about two base pairs of DNA [23]. Association occurs in the micromolar range, is driven by electrostatic interactions and is reversible. At $\mathrm{pH}<6$, such as it occurs in the endosomal compartment, the histidine side chains become positively charged, and about half of the peptides are released from the transfection complex [23]. Concomitantly, solid-state NMR data indicate that under acidic conditions, the packing of the complexes becomes more relaxed [49]. Notably, changes in the lipid composition of the endosomal membranes potentially also have an effect on the membrane association of the peptides and their topologies (orientation relative to the bilayer surface and degree of self-association) [13], the local pH at the membrane surface [32] and thereby endosomal escape. The liberated peptides are now available to interact with the endosomal membranes at high concentrations to cause lysis of the organelle and efficient release of the cargo. With this mechanism in mind, an oligourea foldamer mimetic of LAH4 has recently been designed and has proven to exhibit similar transfection efficiencies when compared with the native sequences [47].

Thus, to develop full transport activity in the endosomes, the peptides need to become significantly more cationic than during the preparation of the complex at $\mathrm{pH} 7.4$ (Table 1). This in turn results in a much increased hydrophobic moment $[14,21]$ and unbinding from the cargo [23]. Indeed, Table 1 indicates that the most active sequences carry a nominal charge of +5 at $\mathrm{pH} 7.4$, which increases to +9 in the endosome. Changes in activity by modification of the overall charge at either $\mathrm{pH} 5$ or 7.4 , re-arranging the charges along the sequence of the peptide, can be rationalized by this structural requirement (Table 1). Furthermore, when viewed along an Edmundson helical wheel, transfection was optimal when the angle covered by the histidines was between 100 and $120^{\circ}$ [5], pointing to the polar angle of the molecule as an important parameter (for definition of polar angle cf. footnote in Table 1). Finally, shortening the core region of the peptide by only two residues much reduces transfection activity [22], which could also contribute to the low efficiency of LAH1, LAH2, LAH3 and LAK4 (Table 1). Notably, many cell-penetrating peptides have been designed where endosomal escape remains a limiting factor [50], a step in the transfection process that does not seem to hamper the activities of several of the LAH4 peptides (Table 1). A previously published model based on a wide range of biophysical and biochemical data summarizes the self-promoted uptake pathway of these histidine-rich compounds [23].

When changing the amino acid sequence, any of the steps involved in the transfection process can be affected. Therefore, it is 
quite difficult to understand in detail how and where such mutations change the flow of events. For example, whereas exchanging an Ala and/or Leu with Phe has relatively little effect on the transfection activities, replacing two Leu with Aib in the sequence abolishes all activities (Table 1). Although such a replacement should not have a major impact on overall hydrophobicity [14], the Aib residue is tetra-substituted at its $\alpha$-carbon. Whereas in crystals, in organic solution or during MD calculations, $\alpha$-helical conformations have been observed for peptides encompassing isolated Aib residues, oligo-Aib peptides prefer $3_{10}$ helical conformations [51,52]. Therefore, in some environments, this bulky residue may shift the conformational equilibria in a subtle manner, thereby also introducing changes in charge distribution and hydrophobic moment, at least during one of the multiple key steps during the transfection process. Whereas an amphipathic $\alpha$-helical conformation may still be obtained in a membrane environment [53], other structures concomitant with changes in peptide self-association may be adopted in aqueous solution [14,32], a notion supported when the CD spectra of LAH4 and LAH4X2 are compared with each other (not shown), or when interacting with the cargo [23]. In this context, it is noteworthy that the transfection efficiency of LAH4 and LAH6 variants has been shown to be affected by their propensity to self-associate in solution [14]. Notably, the helix-breaking proline or the introduction of D-amino acids has been shown to also have pronounced effects on the transfection efficiency [22].

In conclusion, a number of LAH4 peptides have been designed with excellent capacities to non-covalently associate and transport a wide variety of cargoes inside cells where a cell-promoted mechanism assures endosomal escape. Once the cargoes reach the cytoplasm, individual cargoes have particular requirements, which may be influenced by different intracellular fates and destination end points. Therefore, for these later routes to be made more efficient, improvements in the design of these transport complexes may still Q10 be possible [54].

\section{Acknowledgements}

We thank T. Bas Vogt and the team of Luis Moroder, Martinsried, for the initial design and preparation of the first Aib-containing LAH4 peptides and Amélie Martinez, Susan Möller and Delphine Hatey for technical assistance. We gratefully acknowledge Jenny M. Woof, Dundee, for her help and advice on IgG antibodies as well as Louic Vermeer, Regine Süss, Freiburg and Nan Liu, Freiburg, for discussion. The financial contributions of the Agence Nationale de la Recherche (projects TRANSPEP 07-PCV-0018, MemPepSyn 14-CE34-0001-01 and the LabEx Chemistry of Complex Systems 10-LABX-0026_CSC), the University of Strasbourg, the CNRS, the Région Alsace and the RTRA International Center of Frontier Research in Chemistry, Vaincre la Mucoviscidose and the French Foundation for Medical Research (FRM) are gratefully acknowledged.

\section{References}

Q11 1 Hecht S. Huc le. Foldamers: Structure, Properties and Applications. Weinheim: Wiley-VCH, 2007.

2 Bechinger B. Towards membrane protein design: $\mathrm{pH}$-sensitive topology of histidine-containing polypeptides. J. Mol. Biol. 1996; 263: 768-775.

3 Mason AJ, Moussaoui W, Abdelrhaman T, Boukhari A, Bertani $P$, Marquette A, Shooshtarizaheh P, Moulay G, Boehm N, Guerold B, Sawers RJH, Kichler A, Metz-Boutigue MH, Candolfi E, Prevost G, Bechinger B. Structural determinants of antimicrobial and antiplasmodial activity and selectivity in histidine rich amphipathic cationic peptides. J. Biol. Chem. 2009; 284: 119-133.
4 Majdoul S, Seye AK, Kichler A, Holic N, Galy A, Bechinger B, Fenard D. Structural determinants of vectofusin-1 and its derivatives for the enhancement of lentiviral-mediated gene transfer into hematopoietic stem/progenitor cells. J. Biol. Chem. 2016; 291: 2161-2169.

5 Mason AJ, Martinez A, Glaubitz C, Danos O, Kichler A, Bechinger B. The antibiotic and DNA-transfecting peptide LAH4 selectively associates with, and disorders, anionic lipids in mixed membranes. FASEB J. 2006; 20: $320-322$

6 Langlet-Bertin B, Leborgne C, Scherman D, Bechinger B, Mason AJ, Kichler A. Design and evaluation of histidine-rich amphipathic peptides for siRNA delivery. Pharm. Res. 2010; 27: 1426-1436.

7 Gemmill KB, Muttenthaler M, Delehanty JB, Stewart MH, Susumu K, Dawson PE, Medintz IL. Evaluation of diverse peptidyl motifs for cellular delivery of semiconductor quantum dots. Anal. Bioanal. Chem. 2013; 405: 6145-6154.

8 Zhang TT, Khang TH, Ma B, Xu Y, Hung CF, Wu TC. LAH4 enhances CD8+ T cell immunity of protein/peptide-based vaccines. Vaccine 2011; 30: 784-793.

9 Fenard D, Ingrao D, Seye A, Buisset J, Genries S, Martin S, Kichler A, Galy A. Vectofusins, a new class of viral entry enhancers, strongly promote lentiviral transduction of human hematopoietic stem cells. Mol. Ther.-Nucl. Acids 2013; 2. DOI: 10.1038/mtna.2013.17.

10 Liu Y, Kim YJ, Ji M, Fang J, Siriwon N, Zhang L, Wang P. Enhancing gene delivery of adeno-associated viruses by cell-permeable peptides. Mol. Ther.-Meth. Clin. Develop. 2014; 1. DOI: 10.1038/mtm.2013.12.

11 Bechinger B, Vidovic V, Bertani P, Kichler A. A new family of peptidenucleic acid nanostructures with potent transfection activities. J. Pept. Sci. 2011; 17: 88-93.

12 Georgescu J, Verly RM, Bechinger B. NMR structures of the histidine-rich peptide LAH4 in micellar environments: membrane insertion, $\mathrm{pH}$ dependent mode of antimicrobial action and DNA transfection. Biophys. J. 2010; 99: 2507-2515.

13 Perrone B, Miles AJ, Salnikov ES, Wallace B, Bechinger B. Lipidinteractions of the LAH4, a peptide with antimicrobial and nucleic transfection activities. Eur. Biophys. J. 2014; 43: 499-507.

14 lacobucci V, Di Giuseppe F, Bui TT, Vermeer LS, Patel J, Scherman D, Kichler A, Drake AF, Mason AJ. Control of pH responsive peptide selfassociation during endocytosis is required for effective gene transfer. Biochim. Biophys. Acta 1818; 2012: 1332-1341.

15 Aisenbrey C, Goormaghtigh E, Ruysschaert JM, Bechinger B. Translocation of amino acyl residues from the membrane interface to the hydrophobic core: thermodynamic model and experimental analysis using ATR-FTIR spectroscopy. Mol. Membr. Biol. 2006; 23: 363-374.

16 Marquette A, Mason AJ, Bechinger B. Aggregation and membrane permeabilizing properties of designed histidine-containing cationic linear peptide antibiotics. J PeptSci 2008; 14: 488-495.

17 Aisenbrey C, Bechinger B. Molecular packing of amphipathic peptides on the surface of lipid membranes. Langmuir 2014; 30: 10374-10383.

18 Yao L, Langenbacher R, Karabadzhak A, Engelman DM, An M. Visualizing pHLIP insertion in plasmamembrane and endosomal membrane. Biophys. J. 2013; 104: : 238A-A.

19 Mason AJ, Gasnier C, Kichler A, Prevost G, Aunis D, Metz-Boutigue MH, Bechinger B. Enhanced membrane disruption and antibiotic action against pathogenic bacteria by designed histidine-rich peptides at acidic pH. Antimicrob Agents Chemoth. 2006; 50: 3305-3311.

20 Salnikov ES, Mason AJ, Bechinger B. Membrane order perturbation in the presence of antimicrobial peptides by $2 \mathrm{H}$ solid-state NMR spectroscopy. Biochimie 2009; 91: 743.

21 Kichler A, Leborgne C, März J, Danos O, Bechinger B. Histidine-rich amphipathic peptide antibiotics promote efficient delivery of DNA into mammalian cells. ProcNat/AcadSciUSA 2003; 100: 1564-1568.

22 Kichler A, Leborgne C, Danos O, Bechinger B. Characterization of the gene transfer process mediated by histidine-rich peptides. J. Mol. Med. 2007; 85: 191-201.

23 Prongidi-Fix L, Sugewara M, Bertani P, Raya J, Leborgne C, Kichler A, Bechinger B. Self-promoted uptake of peptide/DNA transfection complexes. Biochem.-Us 2007; 46: 11253-11262.

24 Lee Y, Ishii T, Kim HJ, Nishiyama N, Hayakawa Y, Itaka K, Kataoka K. Efficient delivery of bioactive antibodies into the cytoplasm of living cells by charge-conversional polyion complex micelles. Angew. Chem. Int. Ed. Eng. 2010; 49: 2552-2555.

25 Eltoukhy AA, Chen D, Veiseh O, Pelet JM, Yin H, Dong Y, Anderson DG. Nucleic acid-mediated intracellular protein delivery by lipid-like nanoparticles. Biomaterials 2014; 35: 6454-6461. 
26 Schwarze SR, Ho A, Vocero-Akbani A, Dowdy SF. In vivo protein transduction: delivery of a biologically active protein into the mouse. Science 1999; 285: 1569-1572.

27 Postupalenko V, Desplancq D, Orlov I, Arntz Y, Spehner D, Mely $Y$, Klaholz BP, Schultz P, Weiss E, Zuber G. Protein delivery system containing a nickel-immobilized polymer for multimerization of affinity-purified his-tagged proteins enhances cytosolic transfer. Angew. Chem. Int. Ed. Eng. 2015; 54: 10583-10586.

28 Wadia JS, Dowdy SF. Transmembrane delivery of protein and peptide drugs by TAT-mediated transduction in the treatment of cancer. Adv. Drug Deliv. Rev. 2005; 57: 579-596.

29 Mason AJ, Leborgne C, Moulay G, Martinez A, Danos O, Bechinger B, Kichler A. Optimising histidine rich peptides for efficient DNA delivery in the presence of serum. J. Control. Release 2007; 118: 95-104.

30 Coil DA, Miller AD. Enhancement of enveloped virus entry by phosphatidylserine. J. Virol. 2005; 79: 11496-11500.

31 Mislick KA, Baldeschwieler JD. Evidence for the role of proteoglycans in cation-mediated gene transfer. Proc. Natl. Acad. Sci. U. S. A. 1996; 93: 12349-12354.

32 Lan $\mathrm{Y}$, Langlet-Bertin B, Abbate V, Vermeer LS, Kong X, Sullivan $\mathrm{KE}$, Leborgne C, Scherman D, Hider RC, Drake AF, Bansal SS, Kichler A, Mason AJ. Incorporation of 2,3-diaminopropionic acid into linear cationic amphipathic peptides produces $\mathrm{pH}$-sensitive vectors. Chembiochem 2010; 11: 1266-1272.

33 Gerard X, Perrault I, Hanein S, Silva E, Bigot K, Defoort-Delhemmes S, Rio M, Munnich A, Scherman D, Kaplan J, Kichler A, Rozet JM. AONmediated exon skipping restores ciliation in fibroblasts harboring the common leber congenital amaurosis CEP290 mutation. Mol. Ther. Nucl. Acids 2012; 1: : e29.

34 Wade D, Boman A, Wahlin B, Drain CM, Andreu D, Boman HG, Merrifield RB. All-D amino acid-containing channel-forming antibiotic peptides. ProcNatIAcadSciUSA 1990; 87: 4761-4765.

35 Yang Y, Xie X, Xu X, Xia X, Wang H, Li L, Dong W, Ma P, Liu Y, Mei X. Thermal and magnetic dual-responsive liposomes with a cellpenetrating peptide-siRNA conjugate for enhanced and targeted cancer therapy. Colloids Surf. B: Biointerfaces 2016; 146: 607-615.

36 Fowler AV, Zabin I. The amino acid sequence of beta galactosidase. I. Isolation and composition of tryptic peptides. J. Biol. Chem. 1970; 245: 5032-5041.

37 Kozlowski LP. Isoelectric point calculator. http://dxdoiorg/101101/049841 2016.

38 Lewis MJ, Wagner B, Woof JM. The different effector function capabilities of the seven equine IgG subclasses have implications for vaccine strategies. Mol. Immunol. 2008; 45: 818-827.

39 GenBank. Equus caballus partial IGHG7 gene for immunoglobulin gamma 7 heavy chain constant region, exons 1-4 \& Equus caballus im- munoglobulin gamma 4 heavy chain (IGHG4) gene, partial cds. https:// wwwncbin/mnihgov/nuccore/AJ302058 and AY4455181 2016.

40 Abbas AK, Lichtman AH. Cellular and Molecular Immunity, (5th edn). Elsevier Saunders: Philadelphia, 2005.

41 Yang YW, Hsieh YC. Protamine sulfate enhances the transduction efficiency of recombinant adeno-associated virus-mediated gene delivery. Pharm. Res. 2001; 18: 922-927.

42 Fein DE, Limberis MP, Maloney SF, Heath JM, Wilson JM, Diamond SL. Cationic lipid formulations alter the in vivo tropism of AAV2/9 vector in lung. Mol. Ther. 2009; 17: 2078-2087.

43 Xie Q, Bu W, Bhatia S, Hare J, Somasundaram T, Azzi A, Chapman MS. The atomic structure of adeno-associated virus (AAV-2), a vector for human gene therapy. Proc. Natl. Acad. Sci. U. S. A. 2002; 99: 10405-10410.

44 Berns Kl, Hauswirth WW. Adeno-associated viruses. Adv. Virus Res.: Res. Adv. Rabies, Vol 79 1979; 25: 407-449.

45 Bechinger B. Membrane-lytic peptides. Crit. Rev. Plant Sci. 2004; 23: 271-292.

46 Bechinger B. Rationalizing the membrane interactions of cationic amphipathic antimicrobial peptides by their molecular shape. Cur. Opin. Colloid. Interf. Sci., Surfact. 2009; 14: 349-355.

47 Douat C, Aisenbrey C, Antunes S, Decossas M, Lambert O, Bechinger B, Kichler A, Guichard G. A cell-penetrating foldamer with a bioreducible linkage for intracellular delivery of DNA. Angew. Chem. Int. Ed. Eng. 2015; 54: 11133-11137.

48 Xu Y, Liang W, Qiu Y, Cespi M, Palmieri GF, Mason AJ, Lam JK. Incorporation of a nuclear localization signal in $\mathrm{pH}$ responsive LAH4-L1 peptide enhances transfection and nuclear uptake of plasmid DNA. Mol. Pharm. 2016; 13: 3141-3152.

49 Voievoda N. Biophysical investigations of the membrane and nucleic acids interactions of the transfection peptide LAH4-L1. PhD thesis, University of Strasbourg 2014;PhD.

50 Said Hassane F, Saleh AF, Abes R, Gait MJ, Lebleu B. Cell penetrating peptides: overview and applications to the delivery of oligonucleotides. Cell. Mol. Life Sci. 2010; 67: 715-726.

51 Toniolo C, Crisma M, Formaggio F, Peggion C. Control of peptide conformation by the Thorpe-Ingold effect ( $C$ (alpha)-tetrasubstitution). Biopolymers 2001; 60: 396-419.

52 Toniolo C, Benedetti E. Structures of polypeptides from alpha-amino-acids disubstituted at the alpha-carbon. Macromolecules 1991; 24: 4004-4009.

53 Salnikov ES, Friedrich H, LiX, Bertani P, Reissmann S, Hertweck C, O'Neil JD, Raap J, Bechinger B. Structure and alignment of the membraneassociated peptaibols ampullosporin $\mathrm{A}$ and alamethicin by oriented $15 \mathrm{~N}$ and 31 P solid-state NMR spectroscopy. Biophys. J. 2009; 96: 86-100.

54 Gautier R, Douguet D, Antonny B, Drin G. HELIQUEST: a web server to screen sequences with specific alpha-helical properties. Bioinformatics 2008; 24: 2101-2102. 


\section{Special Issue Article}

Histidine-rich designer peptides of the LAH4 family promote cell delivery of a multitude of cargo

Gilles Moulay, Christian Leborgne, A. James Mason, Christopher Aisenbrey, Antoine Kichler and Burkhard Bechinger

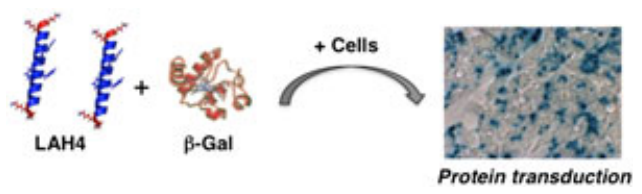




\section{Author Query Form}

\section{Journal: Journal of Peptide Science}

\section{Article: psc_2955}

Dear Author,

During the copyediting of your paper, the following queries arose. Please respond to these by annotating your proofs with the necessary changes/additions.

- If you intend to annotate your proof electronically, please refer to the E-annotation guidelines.

- If you intend to annotate your proof by means of hard-copy mark-up, please use the standard proofing marks. If manually writing corrections on your proof and returning it by fax, do not write too close to the edge of the paper. Please remember that illegible mark-ups may delay publication.

Whether you opt for hard-copy or electronic annotation of your proofs, we recommend that you provide additional clarification of answers to queries by entering your answers on the query sheet, in addition to the text mark-up.

\begin{tabular}{|c|c|c|}
\hline Query No. & Query & Remark \\
\hline Q1 & $\begin{array}{l}\text { AUTHOR: Please confirm that given names (red) and surnames/family names (green) } \\
\text { have been identified correctly. }\end{array}$ & \\
\hline Q2 & AUTHOR: Please check that author affiliations are correct. & \\
\hline Q3 & $\begin{array}{l}\text { AUTHOR: Please supply a graphical table of contents entry with no more than } 80 \text { words } \\
\text { or } 3 \text { sentences of text summarising the key findings presented in the paper and a figure that } \\
\text { best represents the scope of the paper. Kindly note that the image supplied should fit } \\
\text { within the dimensions of } 50 \mathrm{~mm} \times 60 \mathrm{~mm} \text { and be fully legible at this size. }\end{array}$ & \\
\hline Q4 & AUTHOR: Please provide the expanded form of DOTAP if this is an acronym. & \\
\hline Q5 & AUTHOR: Please provide the expanded form of MHC-I if this is an acronym. & \\
\hline Q6 & $\begin{array}{l}\text { AUTHOR: Please provide manufacturer address, that is, company name, city, state (for } \\
\text { US), and country, for Millipore } 9050 \text { automatic peptide synthesizer. }\end{array}$ & \\
\hline Q7 & AUTHOR: Please provide the expanded form of FITC if this is an acronym. & \\
\hline Q8 & $\begin{array}{l}\text { AUTHOR: Figures } 1,3 \text { and GTOC image contain poor quality text. Please check and } \\
\text { advise on how to proceed. }\end{array}$ & \\
\hline Q9 & AUTHOR: Please check the presentation for " 3 h30" if correct. & \\
\hline Q10 & $\begin{array}{l}\text { AUTHOR: Reference } 54 \text { was not cited in the text. It has been inserted here. Please confirm } \\
\text { if this is correct or delete this insertion and indicate where it should be cited or delete the } \\
\text { reference from the Reference List and renumber the References in the text and Reference } \\
\text { List. }\end{array}$ & \\
\hline Q11 & AUTHOR: Please provide the page range for this chapter in Reference. & \\
\hline Q12 & AUTHOR: Please provide the page range for this chapter in Reference. & \\
\hline
\end{tabular}


Required software to e-Annotate PDFs: Adobe Acrobat Professional or Adobe Reader (version 7.0 or above). (Note that this document uses screenshots from Adobe Reader $\mathrm{X}$ )

The latest version of Acrobat Reader can be downloaded for free at: http://get.adobe.com/uk/reader/

Once you have Acrobat Reader open on your computer, click on the Comment tab at the right of the toolbar:

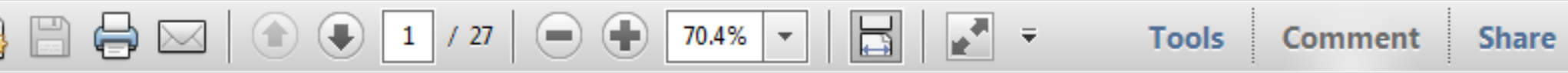

This will open up a panel down the right side of the document. The majority of tools you will use for annotating your proof will be in the Annotations section, pictured opposite. We've picked out some of these tools below:

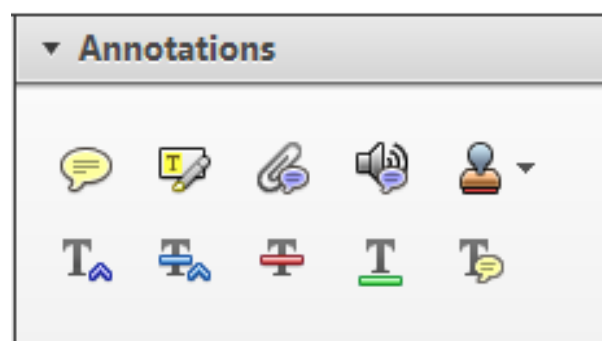

1. Replace (Ins) Tool - for replacing text.

Strikes a line through text and opens up a text box where replacement text can be entered.

How to use it

- Highlight a word or sentence.

- Click on the Replace (Ins) icon in the Annotations section.

- Type the replacement text into the blue box that appears.

Idard tramework for the analysis of $\mathrm{m}$ icy-Nevertheless, it also led to exog،

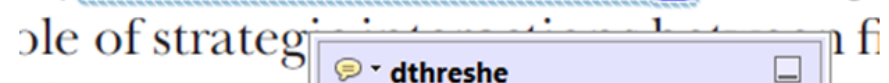
aber of comp 08/06/2011 15:58:17 is that the s1 nain compo: be level, are exc nc

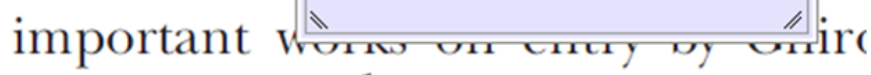
M heneferth) ${ }^{1}$ we anen the "hlarl $\mathrm{l}$

3. Add note to text Tool - for highlighting a section to be changed to bold or italic.

T Highlights text in yellow and opens up a text box where comments can be entered.

\section{How to use it}

- Highlight the relevant section of text.

- Click on the Add note to text icon in the Annotations section.

- Type instruction on what should be changed regarding the text into the yellow box that appears.

namic responses of mark ups ent with the VAR evidence

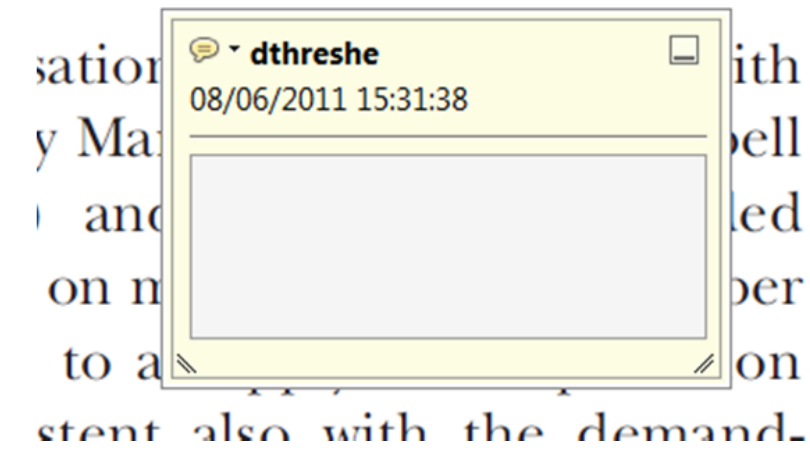

2. Strikethrough (Del) Tool - for deleting text.

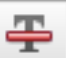

Strikes a red line through text that is to be deleted.

How to use it

- Highlight a word or sentence.

- Click on the Strikethrough (Del) icon in the Annotations section.

there is no room tor extra prohts al c ups are zero and the number of ret) values are not determined by Blanchard and Kiyotaki (1987), sfect competition in general equilil ts of aggregate demand and supply lassical framework assuming monol eph on evorenous number of firme

4. Add sticky note Tool - for making notes at specific points in the text.

Marks a point in the proof where a comment needs to be highlighted.

How to use it

- Click on the Add sticky note icon in the Annotations section.

- Click at the point in the proof where the comment should be inserted.

- Type the comment into the yellow box that appears.

iaisu airu suppiy sirucks. hivsl ui

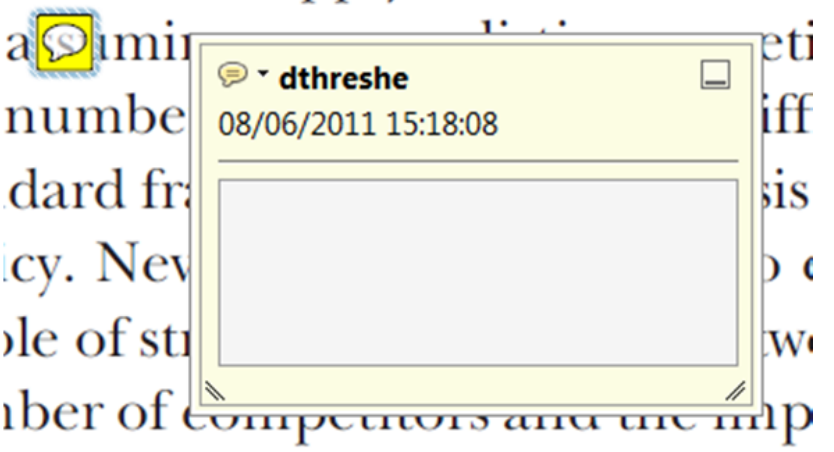

is that the structure of the secto. 
5. Attach File Tool - for inserting large amounts of text or replacement figures.

Inserts an icon linking to the attached file in the appropriate pace in the text.

How to use it

- Click on the Attach File icon in the Annotations section.

- Click on the proof to where you'd like the attached file to be linked.

- Select the file to be attached from your computer or network.

- Select the colour and type of icon that will appear in the proof. Click OK.

E N D

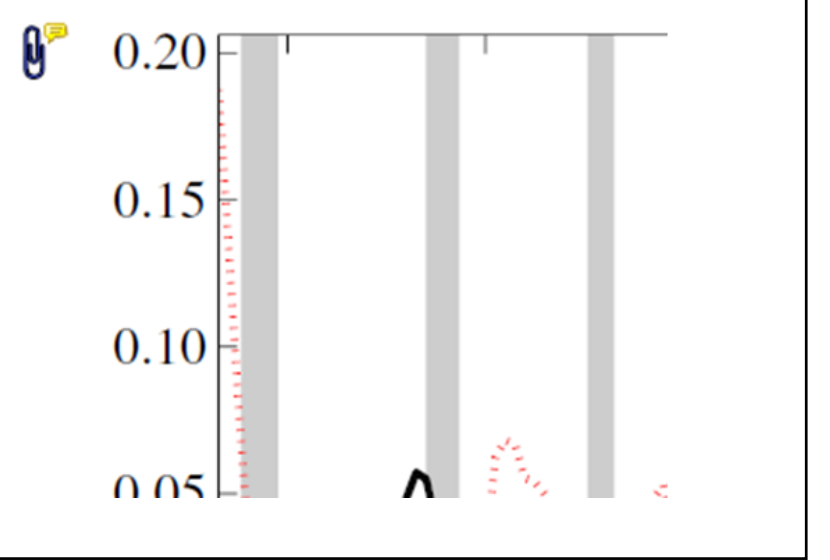

6. Add stamp Tool - for approving a proof if no corrections are required.

- Inserts a selected stamp onto an appropriate place in the proof.

\section{How to use it}

- Click on the Add stamp icon in the Annotations section.

- $\quad$ Select the stamp you want to use. (The Approved stamp is usually available directly in the menu that appears).

- Click on the proof where you'd like the stamp to appear. (Where a proof is to be approved as it is, this would normally be on the first page).

or the business cycie, starting with the on perfect competition, constant ret

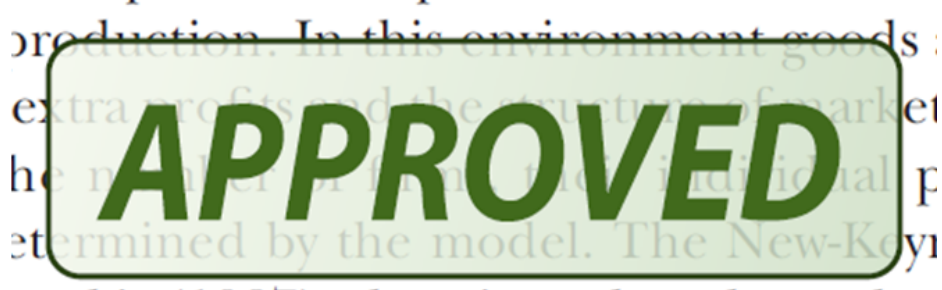
otaki (1987), has introduced produc general equilibrium models with nomin:

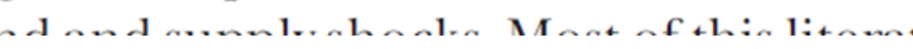

- Drawing Markups

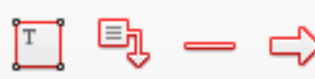

$0 \bigcirc \sqrt{6} \otimes$

\section{How to use it}

- Click on one of the shapes in the Drawing Markups section.

- Click on the proof at the relevant point and draw the selected shape with the cursor.

- To add a comment to the drawn shape, move the cursor over the shape until an arrowhead appears.

- Double click on the shape and type any text in the red box that appears.
7. Drawing Markups Tools - for drawing shapes, lines and freeform annotations on proofs and commenting on these marks.

Allows shapes, lines and freeform annotations to be drawn on proofs and for comment to be made on these marks.

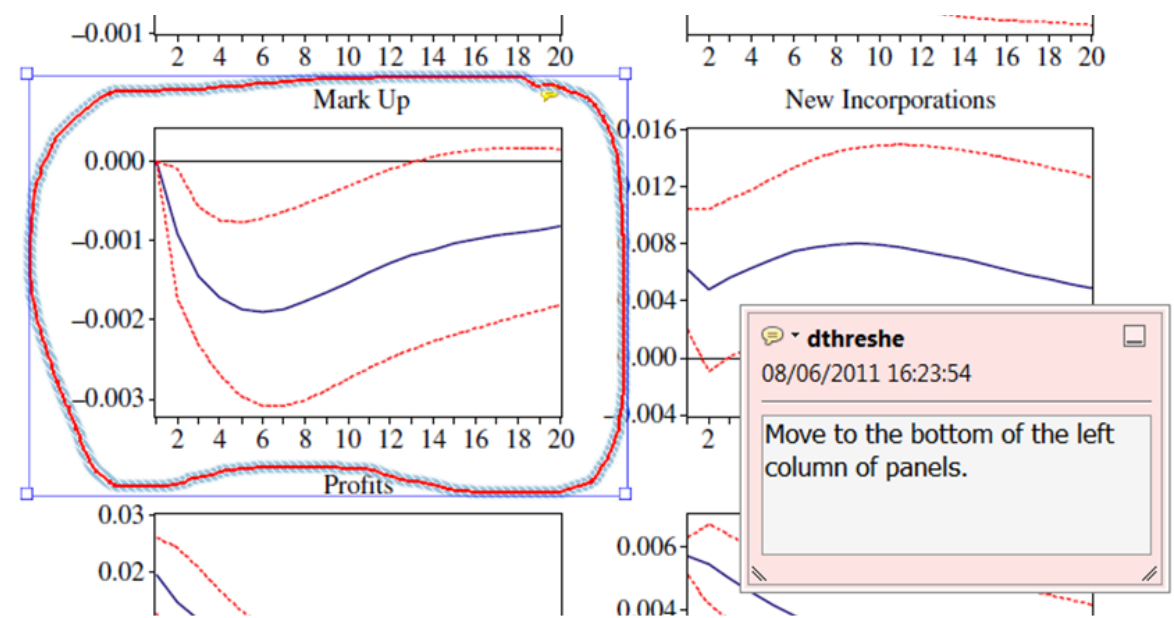

For further information on how to annotate proofs, click on the Help menu to reveal a list of further options:

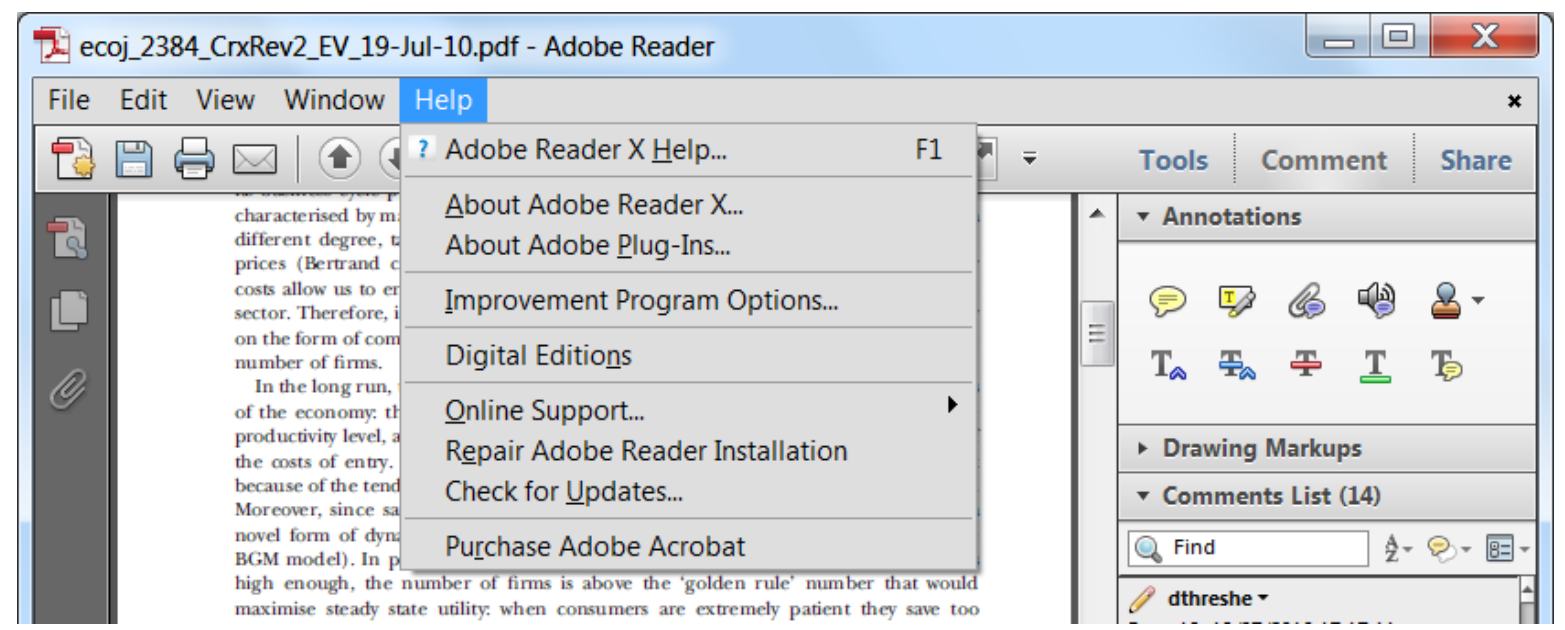

